\title{
Personal Branding dan Diri Otentik Menurut Sartre
}

\author{
Andreas Trianto Soewandi ${ }^{1}$, Robertus Wijanarko ${ }^{2}$ \\ 1,2Program Studi Filsafat Keilahian, Sekolah Tinggi Filsafat Teologi Widya Sasana, Malang, \\ Indonesia \\ Email: andreassoewandi@gmail.com¹, yrnang@yahoo.com²
}

\begin{abstract}
Abstrak
Penulis membahas mengenai Personal-Branding dan Diri Otentik Menurut Sartre. Sejak zaman dahulu, manusia sudah melakukan branding diri sendiri kepada publik. Dengan melakukan branding diri, manusia berusaha menampilkan keahlian dan kebaikan yang ia miliki, meskipun itu bertentangan dengan dirinya yang sebenarnya. Branding diri sangat berkaitan dengan dunia pekerjaan dan nama baik. Branding diri yang baik akan menaikkan nama baik seseorang dan memperoleh kepercayaan masyarakat. Dewasa ini, media sosial tidak lagi menjadi sekedar wadah bagi orang untuk berhubungan. Media sosial telah menjadi sebuah wadah di mana manusia mem-branding diri mereka. Orang menciptakan citra diri mereka sebagaimana mereka ingin dipandang oleh orang banyak. Sartre dalam etikanya menekankan mengenai pentingnya menjadi diri sendiri atau menjadi pribadi yang otentik. Dalam tulisan ini penulis menggunakan metode kajian kritis berdasarkan perspektif eksistensialisme Jean-Paul Sartre. Penulis menemukan bahwa etika Sartre menjadi sebuah kritikan sekaligus pandangan yang akan membebaskan manusia sehingga manusia dapat menjadi dirinya yang otentik dan juga mampu memperoleh kembali kebebasannya. Penulis menyimpulkan bahwa dewasa ini manusia mengalami kekhawatiran akan penilaian orang lain, sehingga mendorong mereka untuk menipu diri sendiri melalui personal branding. Pemikiran Sartre akan membawa manusia kepada kebebasan dan keotentikan diri.
\end{abstract}

Kata kunci: personal branding; kebebasan; kekhawatiran; otentik.

\begin{abstract}
We were discussing about Personal-Branding and self-authenticity by Sartre. Since immemorial time, human have been doing self-branding to the public. It means, human tried to show their skills and goodness they have, even though it is contrary with their-true-self. Self-branding is closely related to the world of work and reputation. A good self-branding will raise their reputation and people's trust. Nowadays, social media is no longer only be a place for people to connected each other. Social media has become a platform where people can branding their self. Human creates their own images as they want to be seen by the others. By Sartre's Ethics, he was pointing the importance of being yourself or being an authentic person. In this paper, I used a critical study method based on the perspective of Jean-Paul Sartre's existenstialism. I find that Sartre's Ethics to be both a criticism and a view to liberate human so that human can be authentic and be able to regain their freedom as well. I conclude that people nowadays are worries about other people's judgement, thus drive them to decieve themself through personal-branding. Sartre's thought will lead human to their liberation and their authenticity.
\end{abstract}

Keywords: personal branding; liberation; worries; authenticity.

\section{Pendahuluan}

Branding berasal dari kata Brand yang memiliki arti identifikasi berupa nama atau simbol yang mempengaruhi proses pemilihan suatu produk atau jasa, yang membedakannya dengan produk pesaing serta memiliki nilai bagi konsumen dan penjualnya (Tamimy, 2017). Branding adalah sebuah teknik marketing yang biasanya digunakan untuk menjual produk atau jasa yang ditawarkan. Dengan branding, masyarakat akan mengenal, mengetahui serta tertarik dan menggunakan produk atau jasa yang ditawarkan. Tanpa adanya branding, sebuah perusahaan yang menawarkan produk atau jasa tidak akan dapat dikenal dan berhasil memasarkan produk maupun jasanya.

Dewasa ini dengan berkembangnya zaman serta media sosial, manusia dapat membranding dirinya di media sosial sehingga dirinya, karya serta jasanya dapat dikenal dan berkembang. Hal ini lebih dikenal sebagai personal branding. Personal branding di media sosial tidak melulu berkaitan dengan proses jual beli produk atau jasa. Personal branding juga dapat mempengaruhi cara pandang orang lain serta dirinya sendiri sebagaimana ia ingin dilihat dan dinilai oleh banyak orang. Personal branding di media sosial kini lebih menyerupai pencitraan diri, 
demi mendapat penonton atau jumlah viewers yang banyak. Personal branding di media sosial juga bisa merupakan sebuah usaha untuk menampilkan "diri ideal" agar terlihat baik oleh orang lain. Jika seseorang ingin terlihat bahagia, ia bisa mem-posting foto atau video yang menampilkan dirinya sedang "tersenyum" dan tampak "bahagia". Orang lain yang melihat unggahan tersebut akan terpengaruh dan persepsinya terbentuk sesuai dengan maksud pengunggah.

Personal branding berkaitan erat dengan nama baik dan kehormatan. Bila seseorang ingin dilihat sebagai pribadi yang baik dan bahagia, ia bisa membentuk dan mengubah persepsi orang lain dengan cara personal branding yang baik. Fenomena personal branding disebabkan oleh ketakutan atau kecemasan dari pribadi akan pandangan atau penilaian orang lain yang buruk akan dirinya. Ketakutan dan kecemasan akan pandangan atau penilaian orang lain mendorong dan memaksa dirinya untuk tampil baik sehingga ia dapat lari dan terhindar dari kecemasannya. Dalam Konteks ini, dapat dibilang bahwa orang tidak lagi bebas menjadi dirinya sendiri. Personal branding tidak menampilkan ke-otentikan pribadi. Selanjutnya, dalam konteks inilah makna dari personal branding dalam keseluruhan tulisan ini dibaca dan dimengerti.

Manusia kini tidaklah bebas dan tidak otentik. la hidup dalam bayang-bayang ketakutan akan penilaian dari yang lain. Kebanyakan manusia sekarang hidup dalam keyakinan yang buruk atau yang disebut dengan mauvaise foi atau keyakinan yang buruk. Di sinilah pandangan Sarte mengenai kebebasan dan diri yang otentik menjadi sebuah kritik sekaligus jalan untuk membebaskan manusia dari ketakutan akan pandangan yang lain sehingga manusia berani menjadi diri sendiri dan memperoleh kembali kebebasannya.

Berdasarkan penjelasan di atas, penulis mengkaji fenomena personal branding. Manusia sekarang merasa cemas dan khawatir akan penilaian orang lain dan membuatnya tidak bebas untuk menjadi diri sendiri. Contoh paling sederhana dan banyak dilihat ialah mengenai fenomena filter untuk foto. Orang dapat membuat fotonya menjadi sangat cantik maupun tampan hanya dengan menggunakan filter. Contoh lain juga ada orang rela hutang demi terlihat kaya di media sosial. Fenomena-fenomena semacam ini membuat orang semakin kehilangan jati dirinya dan kesusahan untuk menjadi dirinya yang otentik. Tulisan ini dibuat untuk mengkritik dan sekaligus menawarkan sebuah pemikiran agar manusia bisa bebas menjadi dirinya sendiri.

\section{Metode}

Tulisan ini menggunakan metode kajian kritis berdasar perspektif eksistensialisme JeanPaul Sartre. Bahan dalam tulisan ini ialah pengertian mengenai Personal Branding, dampak positif dan negatif, dan fenomena yang terjadi di masa kini. Penulis mengumpulkan data dari jurnal-jurnal psikologi dan buku-buku manajemen bisnis yang membahas mengenai fenomena personal branding dan kaitannya dengan kepribadian atau kesehatan mental. Dengan melihat data dari jurnal-jurnal itu, penulis menganalisis dan mengkaji secara kritis berdasar perspektif eksistensialisme Jean-Paul Sartre.

\section{Hasil dan Pembahasan}

Personal branding merupakan hal yang sudah biasa di masa sekarang. Di samping efek positif, personal branding memiliki efek negative bila dimaknai dengan kurang tepat. Kebanyakan pada masa sekarang orang memaknai personal branding secara berlebihan. Di era digital seperti sekarang, kebanyakan orang lebih mementingkan apa yang tampak di dunia maya. Mereka rela memanipulasi atau menipu diri sendiri dan menjadi orang yang jauh berbeda dari dirinya di realita. Bisa jadi juga bahwa dirinya di dunia maya ialah pelarian dari dirinya yang belum bisa menerima dirinya sendiri apa adanya dan berakhir pada memproyeksikan diri idealnya di dunia maya.

Fenomena ini menimbulkan berbagai permasalahan yang pada akhirnya merenggut kebebasan manusia. Manusia tidak lagi bebas menjadi dirinya sendiri. la harus hidup dalam baying-bayang ketakutan dan kekahwatiran akan pandangan dan penilaian orang lain. Karena itu, pandangan Jean Paul Sartre mengenai diri otentik menjadi sangat relevan bagi fenomena sekarang

\section{a. Definisi Personal Branding}

Dalam dunia pasar, branding menjadi suatu hal yang penting. Tanpa branding yang baik dan kuat, sebuah usaha dapat dipastikan kalah dari pesaingnya. Branding juga digunakan oleh pribadi-pribadi dalam menawarkan jasa atau yang disebut dengan personal branding. Dengan melakukan personal branding seseorang akan dikenal kualitas dan nilainya sehingga mendapat respon positif secara emosional dari orang lain (Haroen, 2014). Dengan kata lain, personal branding dapat mempengaruhi pandangan atau persepsi orang lain di banyak aspek dari dirinya sesuai dengan keinginannya. 
Persaingan di dunia baik pasar, politik, industri hiburan, dst, mengharuskan orang untuk menonjolkan keunikan dan keunggulannya dari pesaing-pesaing lain dengan cara membranding dirinya. Melalui personal branding orang dapat membentuk dan menentukan identitasnya. Dengan kata lain, personal branding dapat dijadikan suatu identitas yang digunakan orang lain dalam mengingat seseorang (Stevani dan Widyatmoko, 2017).

\section{b. Media Sosial dan Personal Branding}

Media sosial pada awalnya digunakan untuk menghubungkan manusia yang terpisah oleh jarak. Media sosial menjadi sarana komunikasi. Dalam berkembangnya fitur-fitur media sosial, manusia dapat membangun relasi dan komunikasi dengan manusia baru. Mereka juga dapat membagikan opini, pikiran mereka, foto dan video kegiatan mereka sehari-hari kepada temanteman mereka di media sosial. Media sosial mengatasi persoalan jarak dan waktu dalam berelasi serta berkomunikasi.

Kehadiran fitur-fitur canggih media sosial menambah daya tarik orang untuk menggunakan media sosial. Manusia dapat berbagi mengenai kehidupan mereka dengan orang lain. Pemaknaan penggunaan fitur di media sosial mulai berkembang. Manusia tidak lagi sekedar membagikan keseharian mereka. Manusia mulai memanfaatkan fitur-fitur di media sosial untuk membentuk persepsi orang lain terhadap dirinya. Dengan kata lain, media sosial pada akhirnya menjadi sarana untuk mem-branding dirinya.

Orang banyak berlomba-lomba untuk terlihat baik, bahagia, dan lebih dari orang lain di media sosial. Jumlah like dan followers menjadi tolak ukur keberhasilan seseorang di media sosial. Orang berlomba-lomba mendapatkan jumlah like dan followers yang banyak. Orang tidak lagi sekedar membagikan keseruan aktifitas mereka. Mereka memiliki motif untuk mengejar jumlah like dan followers.

Pergeseran motif dan tujuan media sosial ini berdampak pada perubahan perilaku orang. Manusia tidak lagi menunjukkan ke-otentik-an dirinya lagi. Mereka ingin dirinya selalu tampil baik, bahagia, bergelimang harta, sukses, dst. Mereka menampilkan versi dirinya yang lain, yang bahkan bisa bertolak belakang dari pribadi dirinya sendiri. Pada akhirnya apa yang menjadi tujuannya ialah agar mereka diterima dan diakui oleh orang lain. Mereka mendapat kehormatan dan nama baik.

Dalam konteks ini, melalui personal branding manusia telah kehilangan ke-otentik-an serta kebebasan dirinya. Ketakutan akan pandangan dan penilaian buruk dari orang lain, ketakutan akan tidak diakui keberadaannya, dan ketakutan-ketakutan atau kecemasan lain, membuat manusia kehilangan kebebasan untuk menjadi dirinya sendiri.

\section{c. Persoalan yang Muncul}

Personal branding memiliki efek positif maupun negatif. Namun jika intensi dari melakukan personal branding ialah untuk menghindari pandangan atau penilaian buruk dari orang lain, hal ini akan menimbulkan efek negatif. Berikut beberapa persoalan yang dapat muncul dari personal branding:

\section{1) Sindrom FoMO (Fear of Missing Out)}

Dewasa ini, dunia tengah digemparkan dengan fenomena sindrom FoMO atau sindrom Fear of Missing Out. Sindrom ini banyak dialami oleh anak muda. FoMO atau Fear of Missing Out dapat diartikan sebagai perasaan ketakutan akan kehilangan suatu momen berharga yang melibatkan teman atau kelompok teman sebaya ketika individu absen dari interaksi atau koneksi dengan mereka (Sidik dkk, 2020). Mereka ketakutan kehilangan teman atau bahkan harga diri mereka jika mereka tidak mengetahui apa yang sedang terjadi atau mengenai sesuatu yang lagi tren. Mereka takut mereka kehilangan eksistensi di lingkungan mereka.

Apa hubungan sindrom ini dengan personal branding? Dengan berkembangnya teknologi, informasi semakin mudah didapat. Semua hal yang sedang tren atau viral dengan cepat dapat diakses dan menjadi perbincangan banyak orang. Salah satu cara seseorang dalam personal branding ialah dengan membuat dirinya terus dilihat oleh banyak orang. Untuk dapat menarik perhatian banyak orang, salah satu caranya ialah dengan mengikuti tren yang sedang viral. Dengan mengikuti tren, mereka menampilkan diri sebagai orang yang tidak ketinggalan zaman dan selalu up to date.

Dalam beberapa algoritma media sosial, untuk dapat menjadi trending, salah satu syaratnya ialah konten itu harus mengikuti apa yang sedang viral atau sesuatu yang ramai dibicarakan. Dengan mengikuti cara ini, ia akan mendapat perhatian banyak orang sekaligus membangun branding dirinya. Singkat kata, salah satu cara untuk dapat membangun personal 
branding, seseorang harus terus mengikuti apa yang sedang trending atau ramai dibicarakan. Jika ia kehilangan momentum, ia akan kehilangan perhatian dari banyak orang.

Kehilangan momentum berarti seseorang akan kehilangan daya tarik sekaligus efek yang ditimbulkan dari personal branding pun sedikit. Dengan tidak mengikuti tren, ia kehilangan kehilangan momentum berinteraksi dengan banyak orang. Ketika orang lain berbicara $A$, ia berbicara $\mathrm{B}$. Ketika orang sudah berbicara $\mathrm{C}$, ia masih berbicara mengenai $\mathrm{A}$. Tidak mengikuti tren berarti terputus dari dunia. Seseorang akan dikatakan ketinggalan zaman. Dapat dikatakan bahwa dengan tidak mengikuti sebuah tren, seseorang kehilangan eksistensinya karena terputus dari dunia.

Karena itu biasanya orang yang ingin melakukan personal branding biasanya mengidap sindrom ini. Mereka takut kehilangan momentum dan terputus dari dunia. Terputus dari dunia dapat diartikan sebagai kehilangan eksistensinya. Sindrom ini biasanya diikuti dengan persoalan lain, yaitu kesehatan mental.

\section{2) Kesehatan Mental}

Persoalan lain yang ditimbulkan dari personal branding ialah kesehatan mental. Banyak penelitian telah dilakukan mengenai relasi dari personal branding dan kesehatan mental. Ratarata orang yang terobsesi untuk mem-branding dirinya mengalami masalah dalam kesehatan mental.

Seperti yang dijelaskan di atas mengenai sindrom FoMO, orang yang mengidap FoMO biasanya memiliki masalah dengan kepercayaan diri atau harga dirinya. Ketika seseorang merasa terputus dari dunia, maka ia akan merasa rendah diri, dan mengalami kecemasan serta ketakutan berlebihan (Sidik dkk, 2020). Hal ini dikarenakan mereka ketinggalan sesuatu yang menarik untuk dibicarakan dan dinikmati bersama. Perasaan ketertinggalan dan terputus dari dunia akan memicu ketakutan dan rasa rendah diri. Mengenai hal ini Patti Valkenburg, dkk mencoba untuk membuktikan melalui penelitian yang dilakukan oleh mereka. Dalam penelitian ini mereka menemukan korelasi antara tinggi rendahnya harga diri dengan pengguna sosial media (Valkenburg dkk, 2021). Karena itu harga diri yang rendah dapat menjadi acuan untuk memprediksi pengalaman FoMO.

Selain itu, manusia yang terobsesi untuk mem-branding diri juga rentan untuk mengalami gangguan kesehatan mental. Sindrom FoMO dan keinginan untuk mem-branding diri menjadikan seseorang sebagai pengguna media sosial berat. Penelitian yang dilakukan oleh Sharma, dkk., menunjukkan bahwa manusia manusia yang sering menggunakan media sosial (termasuk orang yang terobsesi mem-branding diri [tambahan penulis]), cenderung mengalami rasa rendah diri, kecanduan media sosial, kurang senang aktifitas offline, cenderung menarik diri dan egois, rentan terhadap stress, dst (Sharma dkk, 2020). Perasaan rendah diri biasanya juga memunculkan sikap pertahanan diri yaitu berupa lari dari diri sendiri. Perrtahanan diri ini meupakan sebuah respon untuk melindungi diri dari perasaan yang membuatnya tidak nyaman. Dan pada kasus ini mereka melarikan diri pada dunia maya dan menciptakan diri ideal yang belum bisa mereka raih.

\section{3) Kebebasan dan Otentisitas Diri}

Dalam usaha mem-branding diri, manusia harus menampilkan sesuatu yang baik dari dirinya, bahkan jika itu bertentangan dengan dirinya. Dengan kata lain apa yang ada di media sosial adalah versi diri yang berbeda dari yang aslinya. Apa yang ditampilkan di media sosial tidak mencerminkan pribadi asli. Kesadaran bahwa media sosial sering kali berbeda dengan kenyataan menciptakan sebuah ungkapan "dunia tipu-tipu". Sebutan ini menggambarkan bahwa apa yang tampil di media sosial seringkali bertolak belakang dari realita.

Seperti yang seringkali diungkap di atas, ketakutan akan pandangan dan penilaian buruk dari orang lain, kehausan akan kehormatan dan nama baik, mendorong seseorang untuk membangun citra diri yang baik melalui media sosial dengan cara mem-branding diri. Ketakutan serta kecemasan yang ada menghilangkan kebebasan dan otentisitas diri.

\section{d. Diri Otentik Sarte}

\section{1) Kebebasan, Bad Faith, dan Otentisitas Manusia}

Eksistensialisme merupakan salah satu jawaban atas pertanyaan manusia mengenai ada. Sejak dahulu pemikiran filsafat dikuasai oleh pandangan esensialisme atau substansialisme. Eksistensialisme membawa sebuah angin segar dan membawa dampak yang besar bagi manusia.

Sartre merupakan salah satu tokoh eksistensialisme. Pemikiran Sartre bertolak dari pemikiran tentang cogito, aku berpikir. Aktivitas berpikir atau cogito bukan berarti pengenalan diri. 
Cogito lebih merupakan sebuah kehadiran kepada dirinya secara non tematis. Sartre mengemukakan bahwa eksistensi mendahului esensi (existence precedes essence).

Apa yang membedakan manusia dari makhluk lain ialah kesadaran, kesadaran akan eksistensinya. Sartre membedakan dua cara mengada yaitu being-in-itslef dan being-for-itself. Being-in-itslef terdapat pada benda mati, karena mereka tidak memiliki kesadaran akan dirinya. Sedangkan being-for-itself ada pada manusia, karena manusia memiliki kesadaran yang terarah pada dirinya. Manusia adalah satu-satunya makhluk yang eksistensinya medahului esensinya: esensi, hakekat seseorang adalah ciptaannya sendiri. Manusia dapat menentukan dirinya melalui sikap dan pilihan-pilihan yang dibuatnya. Segala kondisinya seperti latar belakang keluarga dan masyarakat dan kondisi ekonomisnya tidak menentukan apa itu seseorang: la menentukannya sendiri, dan karena itu apa itu seseorang tidak dapat dipisahkan dari siapa dia itu (Suseno, 2011). Manusia tidak ditentukan berdasar esensinya, melainkan eksistensinyalah yang menentukan esensi manusia. ini berarti bahwa manusia terlebih dahulu bereksistensi, berjumpa, berkiprah di dunia dan baru sesudah itu mendefinisikan dirinya (Tjahjadi, 2011).

Eksistensi manusia ditentukan oleh tindakan yang dilakukan oleh manusia. Manusia memiliki kebebasan dalam dirinya untuk bertindak dan mengarahkan kesadarannya. Bagi sartre, manusia adalah tuan atas hidupnya sendiri. Sartre menolak konsep mengenai Tuhan. Sebab, jika Tuhan ada, maka manusia tidak bebas dalam bertindak dan menentukan dirinya (Bertens, 2014). Bahkan menurut sartre, kebebasan ialah manusia itu sendiri. Manusia bebas menentukan tindakan dan hidupnya. Kebebasan bukan berarti bebas lepas tanpa tanggung jawab. Kebebasan menurut sartre merupakan suatu tahap di mana manusia masuk ke dalam kehidupannya dan bertanggungjawab atas hidupnya sendiri (Mendofra, 2011). Tanggung jawab ini tidak berhenti pada tanggung jawab terhadap orang lain saja. Kebebasan menurut Sartre harus juga harus meliputi tanggung jawab terhadap orang lain (Bertens, 2014).

Konsep kebebasan Sartre menjadi poin penting dalam paham eksistensialisme. Manusia yang bebas adalah manusia yang tidak lagi berada dalam tekanan masyarakat, keluarga, atau norma, bahkan takdir, dalam menentukan hidupnya (Bertens, 2014). Kebebasan manusia ini penulisngnya terletak dalam paradoks kecemasan. Kecemasan yang membuat manusia menjadi bebas. Dalam menjelaskan hal ini sartre memberi contoh sebagai berikut.

Penulis menghadap tepi jurang yang tinggi dan terjal. Penulis menoleh ke dalam. Penulis merasa cemas. Sudah dapat penulis bayangkan apa yang akan terjadi bila penulis menerjunkan diri ke dalam jurang. Sama sekali bergantung pada diri penulis apa yang akan penulis perbuat: terjun ke dalam atau dengan hati-hati melangkah mundur ke tempat yang aman. Tidak ada yang memaksa penulis untuk menyelamatkan hidup penulis dan tidak ada yang menghalangi penulis untuk terjun ke dalam jurang. Bahwa hanya penulis sendirilah yang bertanggung jawab atas perbuatan penulis, mengakibatkan kecemasan. Kecemasan adalah kesadaran bahwa masa depan penulis seluruhnya bergantung pada penulis (Bertens, 2014).

Lebih lanjut Sartre juga memberi contoh kecemasan yang menyangkut masa lampau.

Seorang pemain judi telah mengambil keputusan tidak akan bermain lagi. tetapi keesokan hari ia berada lagi di tempat perjudian. la teringat akan keputusannya hari sebelumnya dan menginsafi bahwa "ketiadaan" memisahkan dia dari masa lampaunya. la harus memutuskan sekarang ini seolah-olah tidak pernah ada keputusan sebelumnya. la merasa cemas karena keputusan yang harus diambil sekarang tidak mempunyai fundamen, juga tidak pada masa lampau. Pertanggungjawaban atas perbuatannya seluruhnya bergantung pada dia pada saat sekarang. Kecemasannya menyatakan kebebasannya (Bertens, 2014).

Kecemasan manusia akan dirinya menyentil kesadarannya untuk bertanggung jawab terhadap hidupnya sendiri. Namun seringkali manusia ingin lari dan menghindari kecemasan yang timbul. Dalam usaha pelariannya sebenarnya juga terkandung kesadaran akan kebebasan, kecemasan, dan pelarian (Bertens, 2014). Tindakan melarikan diri itu merupakan pilihan bebas manusia untuk lari dari kecemasan yang timbul. Di sinilah letak paradoks kebebasan manusia. Manusia mengakui dan sekaligus menyangkal kebebasannya. Sikap inilah yang disebut oleh Sartre sebagai Mauvaise foi (bad faith; sikap malafide).

Apa yang dimaksud Sartre dengan bad faith? Bad faith yang yang dimaksud Sartre adalah tindakan menipu diri (Self-Deception) (Sartre, 1993). Persoalan bad faith adalah mengenai kepercayaan (belief) mengenai diri sendiri. Jika manusia tidak mempercayai diri sendiri melainkan percaya pada kepercayaan lain seperti Tuhan, norma-norma, atau takdir, hal itu menjadikan 
dirinya tidak otentik. Setiap manusia bertanggung jawab atas dirinya sendiri, jika ada orang yang masih percaya pada kepada Allah berarti Allah juga bertanggung jawab atas dirinya sehingga esensi dirinya menjadi tidak otentik (Suseno 2006).

Lalu apa itu diri otentik? Diri otentik merupakan diri yang bebas. Manusia bebas dalam menciptakan makna kehidupan bagi dirinya sendiri daripada sekedar menerima makna dari luar dirinya (Mendofra, 2011). Manusia sungguh bebas dan bertanggung jawab terhadap dirinya. la dapat memaknai hidupnya sendiri. Manusia tidak lagi terikat oleh hukum-hukum Tuhan atau norma-norma masyarakat, stereotipe, atau bahkan "pelabelan" tertentu (Nugroho, 2013). Manusia bebas menjadi dirinya sendiri.

\section{2) Orang Lain adalah Neraka}

Eksistensi Manusia berpusat pada aktifitas menidak (mengatakan tidak). Kesadaran untuk menidak dunia ini selalu terjadi. Dengan tindakan menidak, manusia mempertahankan subjektivitas dan dunianya sendiri (Lanur, 2011). Kesadaran ini juga terjadi pada orang lain. Karena itu pertemuan kesadaran-kesadaran (aku dan yang lain) selalu terjadi dalam dialektika subjek-objek (Lanur, 2011). Aku bertindak sebagai subjek dan orang lain sebagai objek. Demikian sebaliknya, orang lain bertindak sebagai subjek dan aku menjadi objeknya. Pola relasi yang terjadi menjadi atau aku menjadi objek dan orang lain sebagai subjek atau aku menjadi subjek dan orang lain menjadi objek. Pola relasi ini tidak bisa menjadi hubungan subjek-subjek.

Dalam pertemuan antara aku dan yang lain, yang lain melihat aku dengan tatapannya. Sartre menggunakan istilah tatapan dalam arti bahwa ada kehadiran yang lain sebagai subjek yang menonton, menatap, menyelidiki, dan mengobjekkan aku (Lanur, 2011). Begitu juga sebaliknya, aku sebagai subjek dengan tatapanku menjadikan yang lain sebagai objekku. Melalui tatapan mereka, yang lain dapat melihat dan bebas menilai tindakanku. Pengobjektifan aku menuntut diriku untuk merefleksikan diriku sendiri, dan juga tak jarang untuk mengubahku (Tjaya, 2011). Kehadiran yang lain dengan tatapannya, menimbulkan kesadaran bahwa dunia bukan lagi milikku sepenuhnya, melainkan juga milik orang lain (Sartre, 1993). Melalui tatapan yang lain itu juga terbentuklah kesadaran ada-bagi-orang-lain (being-with-others). Tatapan yang lain seakan menelanjangiku dan membuatku terasing. Namun hal ini juga dialami oleh yang lain. Karena itu dalam pembentukan ada-bagi-orang-lain (being-with-others), seringkali timbul rasa bersalah, karena aku membuat orang lain merasa terasing sama seperti yang aku rasakan (Sartre, 1993). Karena inilah Sartre menggambarkan bahwa yang lain adalah neraka bagi diriku.

Kehadiran yang lain dengan tatapannya yang menelanjangiku, menimbulkan persepsipersepsi dan penilaian terhadap diri sendiri yang seringkali negatif. Perasaan takut akan penilaian yang lain seringkali menghambat diriku untuk melakukan sesuatu. Bahkan ketakutan itu mampu membuat diriku berubah menjadi diriku versi lain yang aku sendiri tidak nyaman. Kebiasaan ini oleh Sartre disebut sebagai "mati". Mati ini dalam artian bahwa mereka tidak dapat keluar dari kerangka kekhawatiran, keprihatinan, dna kebiasaan mereka, dan bahwa mereka lalu terus menerus menjadi korban dari penilaian yang diberikan kepada mereka oleh orang lain; dari sudut pandang itu mereka jelas-jelas manusia yang pengecut (Sartre, 1976). Manusia itu terjebak dalam lingkaran setan dan tidak mau menggunakan kehendak bebasnya untuk keluar dan menjadi dirinya sendiri. Mereka inilah yang mengalami kematian yang hidup (living Death) (Tjaya, 2011).

\section{Simpulan dan Saran}

Perkembangan zaman dan teknologi membuat manusia mudah dalam menjalin hubungan dan komunikasi. Seiring berkembangnya ditur-fitur dalam media sosial, pemaknaannya juga mengalami pergeseran. Orang tidak lagi sekedar membagikan aktivitas mereka, tetapi juga sekaligus menjadi ajang untuk mem-branding diri mereka.

Personal branding yang pada mulanya digunakan sebagai teknik marketing, kini merambah masuk pada ranah privat. Dengan personal branding yang baik, mereka dapat meningkatkan nama baik dan kehormatan mereka. Kualitas relasi dengan sesama tidak lagi menjadi hal yang esensial. Jumlah like dan followers menjadi titik tolak atau acuan dalam penilaian diri mereka yang sekaligus menjadi target yang harus dikejar dan terpenuhi. Bila hal tersebut tidak terpenuhi mereka mengalami tekanan dan kekhawatiran akan penilaian buruk dari sekitar.

Pemikiran Sartre mengenai diri yang otentik menjadi kritik atas kehidupan manusia sekarang. Manusia sekarang terlalu peduli terhadap penilaian yang lain terhadap dirinya sehingga mereka berlomba-lomba untuk mem-branding dirinya terlihat lebih baik dan sempurna. 
Idealisme mengenai diri sendiri pada akhirnya membawa mereka pada penderitaan yang berujung pada masalah kesehatan mental.

Pandangan Sartre sungguh menelanjangi sikap dan kebiasaan manusia sekarang dan mengajak manusia untuk berani mengubah keyakinan, pola pikir, dan tindakan mereka. Manusia seharusnya bebas dan bertanggung jawab terhadap diri mereka sendiri. Mereka tidak perlu khawatir berlebihan terhadap penilaian orang lain. Hal ini tidak berarti manusia bisa bebas terhadap orang lain. Dengan menjadi bebas dan otentik, manusia memiliki kewajiban untuk bertanggung jawab terhadap diri sendiri, manusia juga harus bertanggung jawab terhadap orang lain. Contoh sederhana yang dapat dilakukan ialah dengan tidak mempedulikan komentarkomentar negatif orang lain atau komentar-komentar yang tidak membangun; Manusia juga bisa belajar mencintai diri sendiri dan mengapresiasi pencapaian-pencapaian kecilnya; atau juga berteman atau berkumpul dengan lingkungan yang positif akan sangat membantu. Hal-hal sederhana seperti ini dapat menaikkan kepercayaan diri akan mendorong dirinya menjadi diri yang otentik. Semakin ia mencintai dan menghargai diri sendiri, maka seseorang juga semakin menghargai dan bertanggungjawab terhadap orang lain juga semakin bebas menjadi dirinya yang otentik.

\section{Daftar Pustaka}

Bertens, K. 2014. Sejarah Filsafat Kontemporer Prancis Jilid II. Jakarta: Gramedia.

Haroen, Dewi. 2014. Personal Branding Kunci Kesuksesan Anda Berkiprah di Dunia Politik. Jakarta: Gramedia.

Lanur, Alex. 2011. "Relasi Antar-Manusia Menurut Jean-Paul Sartre: Beberapa Catatan". dalam A. Setyo Wibowo. Filsafat Eksistensialisme Jean Paul Sarte. Yogyakarta: Kanisius.

Mendofra, James Farlow. 2011.Eksistensialisme Naturalistik: Kajian Perspektif Naturalistik Terhadap Konsep Eksistensialisme Mengenai Kebebasan dan Faktisitas. Depok: Universitas Indonesia.

Nugroho, Wahyi Budi. 2013. Orang Lain Adalah Neraka. Yogyakarta: Pustaka Pelajar.

Sartre, Jean-Paul. 1943. Being and Nothingness. Diterjemahkan oleh Hazel E. Barnes. 1993. New York: Washington Square Press.

1905-1980. Sartre on Theatre. Diterjemahkan oleh Frank Jellinek. 1976. New York: Pantheon Book.

Sharma, Manoj Kumar, Nisha John, Maya Sahu. 2020. "Influence of Media Social on Mental Health: a Systematic Review". dalam Psychiatry, Medicine, and The Behavioural Sciences. Vol. 33 No. 00.

Sidik, Satria, dkk. 2020. "Peran Harga Diri Terhadap Fear of Missing Out pada Remaja Pengguna Situs Jejaring Sosial". dalam Jurnal Psikologi Teori dan terapan. Vol. 10 No.2.

Suseno, Frans Magnis. 2006. Menalar Tuhan. Yogyakarta: Kanisius.

.2011. "Jean Paul Sartre". dalam A. Setyo Wibowo. Filsafat Eksistensialisme Jean Paul Sarte. Yogyakarta: Kanisius.

Stevani dan Widyatmoko. 2017. "Kepribadian dan Komunikasi Susi Pudjiastuti Dalam Membentuk Personal Branding". dalam Jurnal Komunikasi Fakultas IImu Komunikasi Universitas Tarumanagara. Vol. 9, No. 1.

Tamimy, Muhamad Fadhol. 2017. Sharing-mu Personal Branding-mu. Jakarta: Visimedia.

Tjahjadi, SP. Lili. 2011. "Ateisme Sartre: Menolak Tuhan, Mengiyakan Manusia", dalam A. Setyo Wibowo. Filsafat Eksistensialisme Jean Paul Sarte. Yogyakarta: Kanisius.

Tjaya, Thomas Hidya. 2011. "Relasi Dengan Orang lain dan Paham Kebebasan dalam Drama Sartre Huis Clos". dalam A. Setyo Wibowo. Filsafat Eksistensialisme Jean Paul Sarte. Yogyakarta: Kanisius.

Valkenburg, Patti, , Inne Beyens, J Louwes Pouwels, Irene I van Driel, Loes Keijsers. 2021. "Social Media Use and Adolescents' Self-Esteem: Heading for a Person-specific Media Effects Paradigm". dalam Journal of Communication. Vol. 71. 